\title{
CONFORMACIÓN CORPORAL EN POBLACIONES DE POLLOS PARA CARNE CON DIFERENTE VELOCIDAD DE CRECIMIENTO
}

\author{
Dottavio, A. m. ${ }^{1,3}$; Amoroto, I. ${ }^{1}$; Romera, B. M. ${ }^{1 ;}$ AlvareZ, M. ${ }^{1}$; \\ CANET, Z. E. ${ }^{1,2}$ \& DI MASSO, R. J. ${ }^{1,3}$
}

\begin{abstract}
RESUMEN
La conformación corporal de dos poblaciones de pollos camperos de crecimiento lento (Casilda CP y Campero INTA), en comparación con el parrillero comercial Cobb 500, todos ellos mantenidos en las condiciones de cría establecidas por el protocolo de producción del pollo Campero INTA, se evaluó a igual edad cronológica (51 días) y al mismo peso promedio objetivo de faena, mediante cuatro índices que relativizan las medidas lineales de cada ave [Índice 1 (I1): longitud de la tibia / longitud de la caña; Índice 2 (I2): longitud de la pechuga / ancho de la pechuga; Índice 3 (I3): ancho entre húmeros / ancho entre fémures e Índice 4 (I4): circunferencia corporal / longitud dorsal]. En la comparación a igual edad no se observaron diferencias significativas entre Casilda CP y Campero INTA en ninguno de los índices. Las aves de estos dos grupos se diferenciaron de Cobb 500, en todos los índices, y en ambos sexos, a excepción de los machos Campero INTA con respecto al I3, y de las hembras Casilda $\mathrm{CP}$ con respecto al I4. Las dos poblaciones de crecimiento lento presentan a esa edad temprana, tanto en machos como en hembras, menores valores del I1, mayores valores del I2, mayores valores del I3 y menores valores del I4. Comparados al mismo peso corporal no se observaron diferencias entre los dos grupos de crecimiento lento en ninguno de los cuatro estimadores, a excepción del I2 en hembras, que presentó valores mayores en Campero INTA. I3 presentó valores similares en los tres genotipos. Cobb 500 mostró, en ambos sexos, menores valores promedio del I1 y del I2, y mayores valores del I4. Los resultados muestran que las aves de crecimiento lento, si bien presentan un buen desarrollo muscular, a diferencia de los antiguos pollos de campo, mantienen cierto grado de dimorfismo sexual propio de la especie y exhiben un fenotipo característico, que puede ser descrito como "tipo faisán", que los identifica y distingue de los híbridos industriales de fenotipo compacto.

Palabras clave: longitud corporal, ancho corporal, circunferencia corporal, pollo parrillero, pollo campero.
\end{abstract}

1.- Cátedra de Genética. Facultad de Ciencias Veterinarias (UNR). Ovidio Lagos y Ruta 33, (2170)

Casilda, provincia de Santa Fe.

2.- Sección Avicultura. EEA INTA Pergamino

3.- Carrera del Investigador Científico CIC-UNR. Universidad Nacional de Rosario.

Manuscrito recibido el 27 de diciembre de 2010 y aceptado para su publicación el 30 de marzo de 2011 


\section{SUMMARY}

\section{Body conformation in meat type chicken populations with different growth rate.}

Body conformation of two slow-growing free-range chickens populations (Campero INTA and Casilda CP) compared with the Cobb 500 commercial broiler, all kept in the same rearing conditions set by the protocol of Campero INTA production, was evaluated at the same chronological age (51 days) and at the same average target slaughter weight by means of four indexes that relate the linear measurements of each bird [Index 1 (I1): tibia length/shank length; Index 2 (I2): breast length/breast width; Index 3 (I3): width between humerus/width between femurs and (I4), body circumference/ dorsal length. When compared at the same age non significant differences were observed between Casilda CP and Campero INTA. Birds of these two groups differed from Cobb 500 at all levels and in both sexes, except for Campero INTA males with respect to I3, and Casilda CP females with respect to I4. At this early age both males and females from the two slow-growing populations presented lower I1 values, higher values of I2 and I3, and lower I4 values than Cobb 500 broilers. At the same body weight there were no differences between the two slow-growing groups in any of the four estimates, with the exception of I2 in females, which showed higher values in Campero INTA. I3 showed similar values in the three genotypes. Cobb 500 showed, in both sexes, lower average values of I1 and I2, and higher values of I4. The results show that slow-growing birds, although having a good breast muscle development unlike the old field chickens, maintain a certain degree of sexual dimorphism typical of the species, and exhibit a characteristic phenotype which can be described as "pheasant-type" and allows identifying and distinguishing them from the industrial hybrid compact phenotype.

Key words: body length, body width, body circumference, broiler, free range meat chicken. 